by A.K. Jain ${ }^{*}$, P.K. Mukherjee ${ }^{2}$ and Saurabh Singhal ${ }^{2}$

\title{
Terrane characterization in the Himalaya since Paleoproterozoic
}

\author{
*1 CSIR-Central Building Research Institute, Roorkee-247667 (India) \\ \#2 Wadia Institute of Himalayan Geology, Dehradun-248 001 (India) \\ ${ }^{* 3}$ IUAC-National Geochron Facility, New Delhi 110067 (India) \\ * Corresponding Author: E-mail: himalfes@gmail.com
}

(Received : 23/10/2018; Revised accepted : 19/08/2019)

https://doi.org/10.18814/epiiugs/2020/020021

In the Himalaya, distinct terranes are juxtaposed across the Main Central Thrust Zone (MCTZ) where subthrust Inner Lesser Himalaya (iLH) sedimentary belt yielded nearly unimodal $\mathrm{U}-\mathrm{Pb}$ detrital zircon (DZ) between 2.05 and $1.80 \mathrm{Ga}$. Within this thrust zone, orthomylonite and other lithologies represent the Proterozoic magmatic arc with zircon having $U-P b \sim 1.95$ to 1.89 Ga crystallization ages; together, these represent the Columbian Supercontinent assembly. In contrast, first appearance of the Neoproterozoic 1.05-0.85 Ga zircon characterizes the overthrust Great Himalayan Sequence (GHS-Vaikrita Group) along the Main Central Thrust (MCT), while early Paleozoic detrital zirconhas first appearance in tectonically overlying Tethyan Himalayan Sequence (THS).

The iLH sediments were possibly derived both from a northernly 1.9 Ga magmatic arc and the ArcheanProterozoic Aravalli-Bundelkhand nuclei of the Indian craton. Source rocks for Neoproterozoic zircon in the GHS-a distinct terrane in the Himalaya-may possibly be the Neoproterozoic magmatic bodies within the GHS and 'In-board' Aravalli-Delhi Fold Belt (ADMB)Central Indian Tectonic Zone (CITZ), though northern 'Off-board' sources cannot be ruled out, altogether.

\section{Introduction}

Zircon $\left(\mathrm{ZrSiO}_{4}\right)$ is present in all the rock types throughout the Earth's geological history as accessory mineral, and survives extreme geological processes like transportation, deformation, metamorphism and crustal anataxis. Uranium-Lead (U-Pb) dating of zircon has extensive applications in stratigraphic correlation, timing of magmatic and metamorphic events, source rock characterization, sediment transport and dispersal patterns in almost all the orogenic belts and cratons for tectonic interpretations and paleogeographic reconstructions (Fedo et al., 2003; Gehrels, 2014). Dating methods by the Laser Ablation Multi-collector Inductively-Coupled Plasma Mass Spectrometer (LA-MC-ICPMS) has recent been perfected, hence very large and precise data sets on $\mathrm{U}-\mathrm{Pb}$ zircon ages are now effectively generated in relatively less time at low cost (Gehrels, 2014). Determination of maximum depositional ages of unfossiliferous sedimentary units, mainly of the Archean and Proterozoic Era, is now carried out by analyses of large number of detrital zircon (DZ) by using the youngest age population (Fedo et al., 2003; Gehrels, 2014).

In the Himalaya, U-Pb geochronology of zircon is applied for correlation, tectonics and terrane characterization (DeCelles et al., 2000; Kohn et al., 2010; Gehrels et al., 2011; Myrow et al., 2016). The Sub-Himalayan (SH) belt, the Lesser Himalaya (LH) sedimentary belt, the Main Central Thrust Zone (MCTZ), Great Himalayan Sequence (GHS) and the Tethyan Himalayan Sequence (THS) are tectonically juxtaposed from south to north during the Cenozoic; each of these units are demarcated by major tectonic boundaries. Attempts are made to reconstruct their original configuration and sources of the Proterozoic Neoproterozoic Paleozoic sedimentary sequences, prior to the Cenozoic Himalayan orogenesis (DeCelles et al., 2000; Myrow et al., 2010; Yin et al., 2010; Gehrels et al., 2011; Spencer et al., 2018).

The main objective of this contribution is to address and apply zircon $\mathrm{U}-\mathrm{Pb}$ geochronology to various lithotectonic units in the identification of distict terranes, prior to the Himalayan orogenesis. This paper proposes that the GHS is a distinct identifiable terrane from the Inner Lesser Himalaya (iLH) sedimentary belt, the MCT zone and the overlying THS. Regional correlations reveal distinctions and/or similarities of the GHS with the Outer Lesser Himalayan (oLH) sedimentary belt further south. Sources of the Archean Proterozoic Neoproterozoic zircon from these regionally-defined domains are probed for postulating tectonic models during the pre-Himalayan geological history for better assessment of assembly and break-up of the Columbian and Rodinia Supercontinents.

\section{Regional geological framework}

Four longitudinal arcuate and continuous thrust-bound tectonic belts characterize the Himalaya between the Indo-Gangetic Plains and the Indus Tsangpo Suture Zone, and possess distinct lithologies 
and geological histories (Fig. 1; Gansser, 1964; Thakur 1993; Hodges, 2000; Yin, 2006; Jain et al., 2014; Valdiya, 2015).

\section{Sub-Himalayan (SH) Foreland Belt}

The SH is an elongated arcuate belt between the Main Frontal Thrust (MFT) towards the south and the Main Boundary Thrust (MBT) in the north, and evolved with widespread Paleocene-Middle Eocene marine transgression containing Subathu Formation (shalesandstone-limestone) in an asymmetrical basin. The basin predominantly accumulated fluvial sediments of the Dagshai-KasauliSiwalik Groups (sandstone-shale-mudstone-conglomerate) during Oligicene-Pleistocene, which were deposited by southward-flowing river systems from the rising Himalaya (Srikantia and Bhargava, 1998).

\section{Lesser Himalayan (LH) Belt}

This belt is characterized by three sub-units between the MBT and the Main Central Thrust (MCT): (i) Neoproterozoic-EarlyPaleozoic Outer Lesser Himalayan (oLH) sedimentary belt of the Neoproterozoic-Paleozoic-Mesozoic-Eocene Shimla-Jaunsar-BlainiKrol-Tal-Subathu Groups between the MBT and the Tons Thrust (TT) / North Almora Thrust (NAT). (ii) Synformal klippen of the Lesser Himalayan Crystalline (LHC) nappe (Jutogh-GarhwalAlmora-Baijnath-Askot-Chiplakot- Kathmandu), thrust over the LH sedimentary belt (Valdiya, 1980). The lowermost Kulu-BajuraRamgarh Nappe of an extensive ca. 1.85 Ga Ramgarh-Ulleri-type mylonite orthogneiss is overlain by quartzite-phyllite-rich Nathuakhan Formation with $0.80 \mathrm{Ga}$ as youngest detrital zircon (Célérier et al.,
2009; Mandal et al., 2015). The Almora Nappe overrides this unit, with ca. $1.85 \mathrm{Ga}$ mylonitized granite gneiss along the base, garnetiferous quartzite-schist alternations with 0.85 to $0.58 \mathrm{Ga}$ youngest detrital zircon and $0.55 \mathrm{Ga}$ intrusive granitoids (Trivedi et al., 1984; Mandal et al., 2015). (iii) An Inner Lesser Himalayan (iLH) sedimentary belt between the TT/NAT and the MCT with the Paleoproterozoic Rautgara-Gangolihat-Deoban-Berinag-KushmaDaling-Shumar Groups (Valdiya, 1980; Jain et al., 2014), having maximum depositional age of 1.85-1.80 Ga (Célérier et al., 2009; McKenzie et al., 2011; Mandal et al., 2016).

\section{Higher Himalayan Crystalline (HHC) belt}

Between the Munsiari Thrust (MT) and the South Tibetan Detachment System (STDS), this belt contains: (i) an outer intensely mylonitized Munsiari Group belt (Lesser Himalayan CrystallinesLHC/Kulu-Bajura-Ulleri nappe), and (ii) slab-like north-dipping 15 km thick Great Himalayan Sequence (GHS) belt/Vaikrita Group/ Tibetan Slab, bounded by the Vaikrita Thrust (VT) and the STDS along the lower and upper margins, respectively (Spencer et al., 2012; Jain et al., 2014).

The Munsiari-Ulleri Group contains intensely mylonitized and imbricated Paleoproterozoic megacryst granite gneiss, fine grained biotite paragneiss, garnetiferous mica schist, phyllonite and sheared amphibolite. In Alaknanda valley, sericite-bearing sheared foliated quartzite is imbricated and resembles the Berinag Group quartzite. The belt is regionally thrust over the iLH along the Munsiari Thrust (MT-Valdiya, 1980) - the Main Central Thrust-MCT sensu stricto (cf., Heim and Gansser, 1939).

The overlying Vaikrita Group contains garnet-kyanite-biotite-

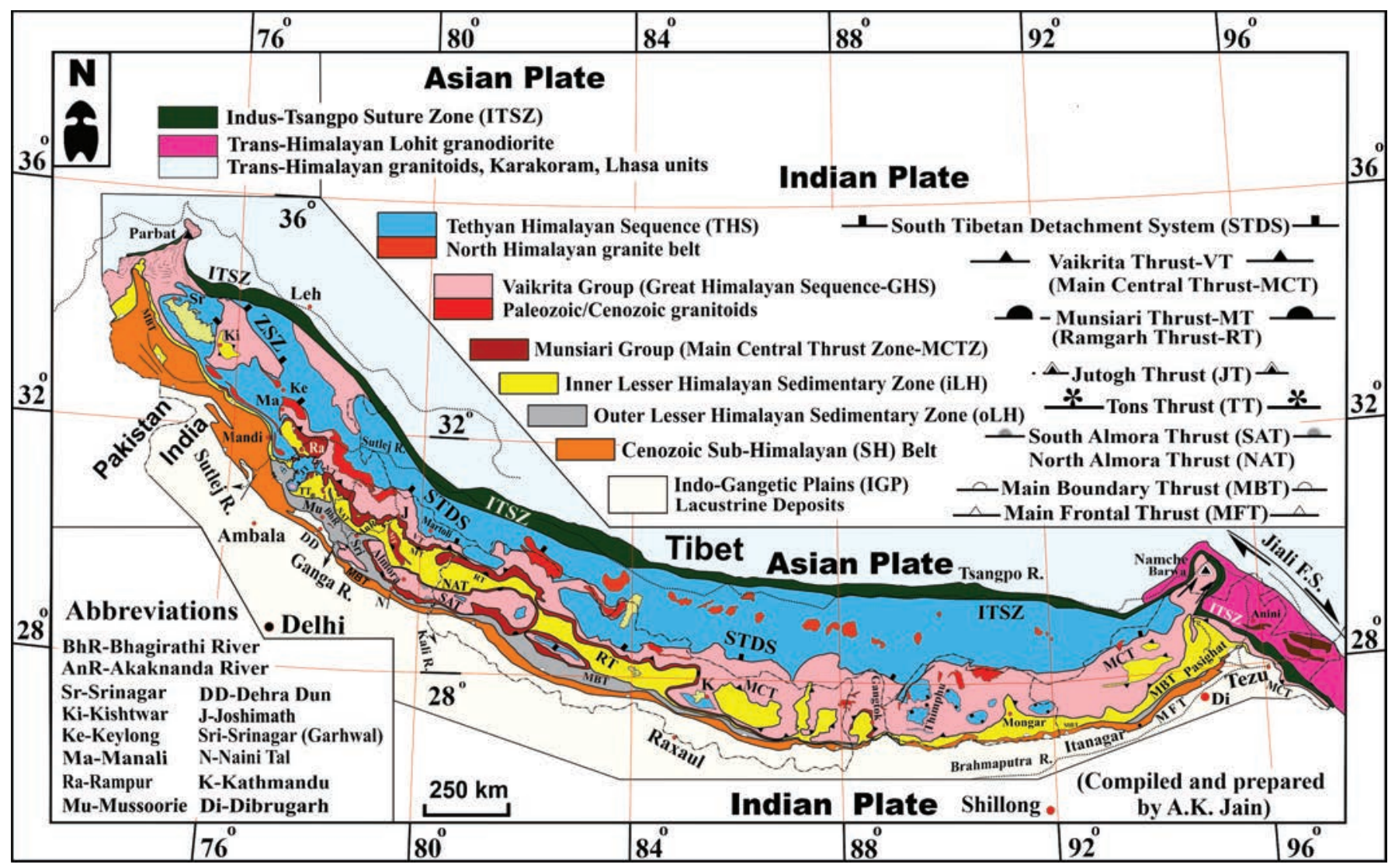

Figure 1. Geological map of the Himalaya and distribution of main litho-tectonic units. Compiled after various published sources. 
muscovite schist/psammitic gneiss in lower parts, while it becomes sillimanite-bearing schist/psammitic gneiss with calc silicates and garnet amphibolite in the upper parts. Regionally, pervasive migmatite and leucogranite appear at the highest levels. This belt is metamorphosed under lower to upper amphibolite and rarely granulite facies, and exhibits typical inverted metamorphism. In parts of Tons, Pabbar, Satluj and Beas valleys, low to medium grade Jutogh Nappe, exposed between the oLH/iLH and MCTZ, joins the basal parts of the Tethyan Himalayan Sequence (THS).

\section{Tethyan Himalayan Sequence (THS)}

Late Proterozoic-early Paleozoic Martoli/Ralam/Haimanta Formation and fossiliferous Paleo-Mesozoic sedimentary sequence of the THS make up this sequence above the GHS, and are separated by north-dipping extensional South Tibetan Detachment System (STDS).

\section{Regional U-Pb zircon age patterns}

\section{Outer Lesser Himalayan Sedimentary Belt (oLH)}

Within the oLH belt, the oldest Mandhali Formation possesses the youngest 0.95 Ga detrital zircon (DZ) peak (Fig. 2n), which becomes gradually younger within the Jaunsar Group - the Chandpur Formation ( 0.88 Ga) and Cryogenian Nagthat Formation ( 0.82 Ga)
(Figs. 2o-q; Myrow et al., 2003; Célérier et al., 2009; Hofmann et al., 2011; McKenzie et al., 2011). This belt has a distinct DZ population with incoming of younger $\sim 0.70 \mathrm{Ga}$ grains in the Marinoan Blaini diamictite (Figs. 2r-u), $\sim 0.70 \mathrm{Ga}$ in the Krol sandstone (Fig. $2 v$ ) and $\sim 0.525$ Ga in late Early Cambrian lower Tal trilobite-bearing strata (Figs. 2w-y; Myrow et al., 2003, 2010; Hofmann et al., 2011; McKenzie et al., 2011).

\section{Late Paleoproterozoic Inner Lesser Himalaya (iLH)}

An association of quartzite-limestone-slate-metavolcanics of the Rautgara-Gangolihat-Deoban-Berinag-Kushma-Daling-Shumar sequences within the iLH is exposed beneath the overthrust Munsiari Thrust from Kashmir to Arunachal Pradesh (Valdiya, 1980; DeCelles et al., 2000; Kohn et al., 2010; Yin et al., 2010).

Along the Sutlej valley in the Kulu-Rampur window, the Rampur Group has youngest U-Pb DZ ages between 1.92 and 1.88 Ga (Fig. 2e; Richards et al., 2005; Webb et al., 2011), constraining its maximum depositional age. U-Pb zircon crystallization ages of $1800 \pm 13$ and $1840 \pm 16$ Ma from the Rampur metabasalt-metarhyodacite flows (Miller et al., 2000) and the intrusive Bandal granite of 1856 $\pm 3 \mathrm{Ma}$ (Singh et al., 2009) further provide constrains to its age. Beneath the Askot Nappe, the Berinag Group contains 1.86 Ga DZ peak (Fig. 2a; Mandal et al., 2016) and 1.87 Ga peak in its type area, while the lowermost Rautgara-Damtha formations yielded peaks of 1.75, 1.88

a)

Ga

b)
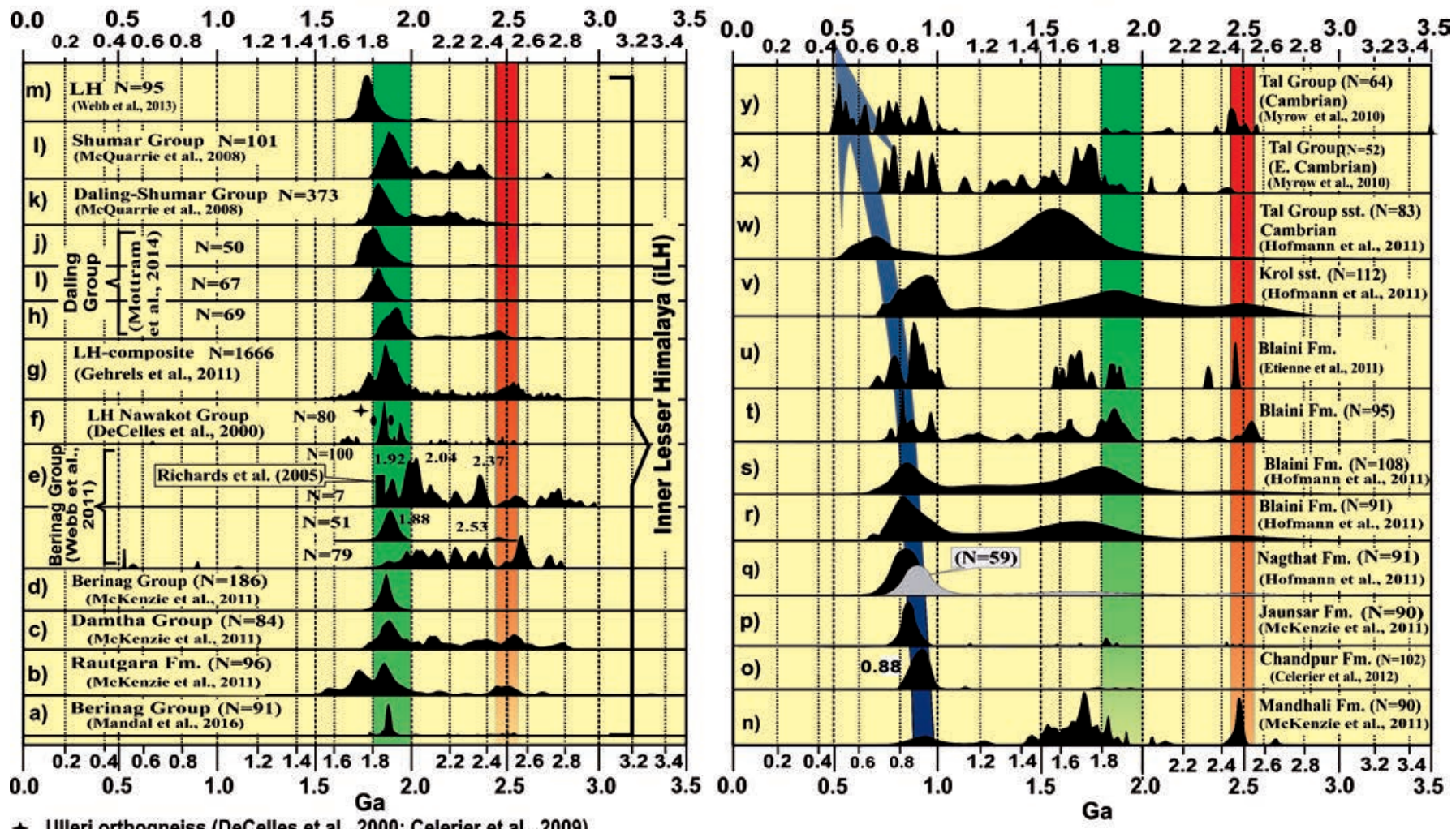

+ Ulleri orthogneiss (DeCelles et al., 2000; Celerier et al., 2009)

Figure 2. Probability distribution plots of the U-Pb zircon ages from the Inner Lesser Himalaya (iLH) and comparison with the Outer Lesser Himalayan (oLH) Sedimentary Belt. Common distribution of 2.5 Ga and 2.0-1.8 Ga zircon shown by vertical columns, while the Neoproterozoic zircon make the oLH with appearance of the early Paleozoic and a younging pattern. Data sources in parenthesis (see references). ' $n$ '=number of the U-Pb zircon analyses. 
and 2.50 Ga (Figs. 2b-d; McKenzie et al., 2011). In southernmost parts, the Bhowali quartzite has similar DZ population near the MBT (Mandal et al., 2015).

In Central and Eastern Himalaya, DZ ages are almost indistinguishable from each other in this belt; Nepal exhibits dominant DZ grain population between 2.0 and $1.7 \mathrm{Ga}$, minor peaks between 2.6 and 2.4 Ga (Figs. 2f, g; Parrish and Hodges, 1996; DeCelles et al., 2000, 2001; Kohn et al., 2010; Gehrels et al., 2011 and references therein; Martin et al., 2005, 2011, 2017; Khanal et al., 2015). The Daling Group quartzite in Sikkim yielded U-Pb DZ peaks between 1.90 and $1.80 \mathrm{Ga}$ and minor Neoarchean and lower Proterozoic components (Figs. 2h-j; Mottram et al., 2014). In central Bhutan, the Daling-Shumar contact is marked by the DZ peak at $1.90-1.80 \mathrm{Ga}$, smaller peak around $2.50 \mathrm{Ga}$, and interstratified metarhyolite with 1.89-1.79 Ga zircon, thus confirming the depositional age of these formations 1.90 Ga (Figs. 2k-l; McQuarrie et al., 2008, 2013). It is, however, slightly younger ( $1.78 \mathrm{Ga}$ ) in western Arunachal Pradesh (Fig. 2m; Webb et al., 2013).

Detrital zircon age data from nearly whole of the iLH domain, therefore, provide undisputed evidences that the above sheet-like matured Paleoproterozoic sedimentary sequences were the deposited between $\sim 1.90$ and $1.80 \mathrm{Ga}$. Further, a stratigraphic break of $\sim 1.0 \mathrm{Ga}$ is also recorded between the iLH and oLH sedimentary basins throughout the Himalaya.

\section{Munsiari Group (Main Central Thrust Zone- MCTZ)}

This belt contains far-traveled highly sheared and folded Munsiari Group - the Main Central Thrust Zone (MCTZ), whose remnants are observed in mylonitized Askot-Baijnath-Chiplakot nappe, the basal Almora Nappe mylonite and the Ramgarh mylonitein Uttarakhand. The Late Paleoproterozoic magmatic arc (Kohn et al., 2010) of the imbricated Munsiari-Baragaon mylonite belt of the Kulu-Bajura nappe in Himachal and the Munsiari Group in Uttarakhand, intervenes the iLH belt and the GHS between Ravi and Kali Rivers. In the Alaknanda valley, this belt yielded ${ }^{207} \mathrm{~Pb} /{ }^{206} \mathrm{~Pb}$ ages between 1.95 and $1.89 \mathrm{Ga}$ (Spencer et al., 2012), this age is replicated in its strike continuity between 1.97 and 1.95 Ga along the Kali valley (Phukon et al., 2018).

Remnants of the LH crystalline nappe, representing southward extension of this arc, contain $\sim 1.85$ Ga zircon in the ChiplakotBaijnath-Askot-Ramgarh-Almora Crystallines (Fig. 3). From the Chiplakot klippe, mylonitized augen gneiss has a 1.92 Ga age (Phukon et al., 2018). In extreme south, the Ramgarh orthomylonite has ${ }^{207} \mathrm{~Pb} /$ ${ }^{206} \mathrm{~Pb} \sim 1.87$ Ga zircon age (Celerier et al., 2009; Mandal et al., 2015, 2016); WR Rb-Sr 1820 \pm 130 Ma isochron age from the basal Almora nappe granitoids (Trivedi et al., 1984) broadly resembles the U-Pb zircon age of this belt. Widely-distributed protolith crystallization age of $\sim 1.901 .85 \mathrm{Ga}$ characterizes this magmatic arc between Beas and Sutlej valleys, and represents contemporaneous felsic plutonism during the evolution of this arc (Singh et al., 2006, 2009; Kohn et al., 2010; Webb et al., 2011).

On the basis of texture, geochemistry and new zircon U-Pb age data from numerous magmatic bodies including the Ulleri orthogneiss mylonite, Kohn et al. (2010) proposed a Paleoproterozoic active magmatic arc between 1.88 and $1.78 \mathrm{Ga}$ (Fig. 2f).The Ulleri mylonite granitoid intruded the Kuncha schist, which contained largest $~ 1.90$ Ga DZ peak, thus constraining its maximum depositional age (Martin et al., 2011), like intrusive mylonitized augen gneiss of $\sim 1.75 \mathrm{Ga}$ along the Kodari section (Khanal et al., 2015).

In Sikkim and Central Bhutan, sheared orthogneiss in the MCTZ possesses ${ }^{207} \mathrm{~Pb} /{ }^{206} \mathrm{~Pb}$ zircon ages between 1.90 and $1.83 \mathrm{Ga}$, with older inherited Neoarchean and Proterozoiccores (McQuarrie et al., 2013; Mottram et al., 2014). The 1.75 Ga mylonite gneiss from the MCT zone in western Kameng and Subansiri regions of Arunachal

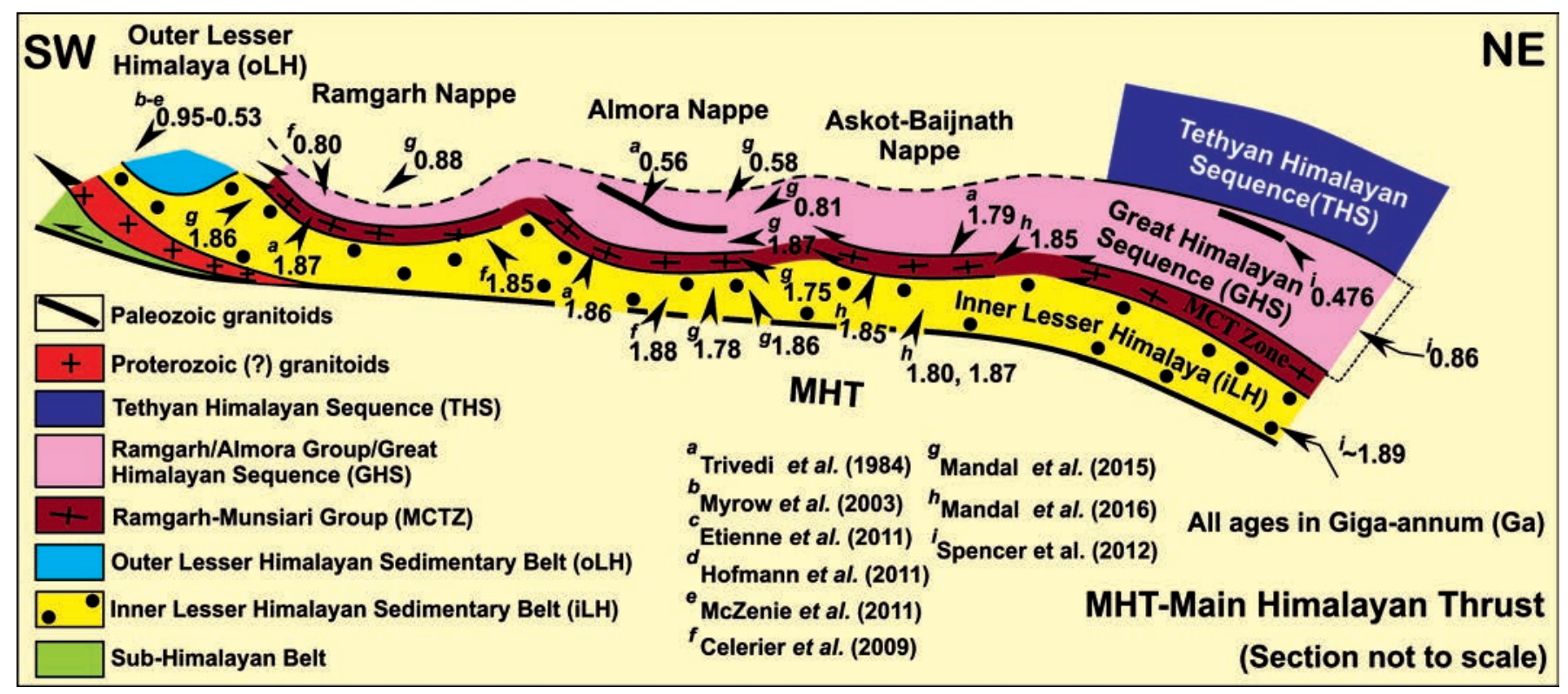

Figure 3. Schematic NE-SW tectonic cross-section of the Uttarakhand Himalaya, showing distribution of different units and their U-Pb zircon ages. U-Pb crystallization ages of the Ramgarh-Munsiari groups-MCT Zone mylonite (Paleoproterozoic magmatic arc) are shown along with youngest depositional ages of sediments in other units by their peak zircon ages. The Almora Nappe is shown distinct from the Ramgarh Nappe. Data sources: a-Trivedi et al. (1984). b-Myrow et al. (2003). c-Etienne et al. (2011). d-Hofmann et al. (2011). e-McKenzie et al. (2011). f-Celerier et al. (2011). g-Mandal et al. (2015). h-Mandal et al. (2016). i-Spencer et al. (2012). 
Pradesh possibly represents somewhat younger phase of this arc (Yin et al., 2010). From the Bomdila granite gneiss in western Kameng, Pathak and Kumar (2019) obtained weighted mean ${ }^{207} \mathrm{~Pb} /{ }^{206} \mathrm{Pbage}$ of $1752 \pm 23 \mathrm{Ma}$ as its crystallization age of zircons, which coincided with a period of magmatism within the Columbia supercontinent accretionary orogen and involvement of ancient continental crust.

This belt has almost similar zircon ages like the iLH sequences throughout the Himalaya and is visualized as the main Paleoproterozoic magmatic arc with the iLH as the back-arc; the latter derived its detritus, both from eroded magmatic arc in the north and the Indian craton along the southern margin (see later section).

\section{Great Himalayan Sequence (GHS) Belt}

This belt incorporates high grade metamorphosed Vaikrita Group (Tibetan Slab) in the north and metasediments of the Askot-BaijnathAlmora-Ramgarhklippen of an extensive metamorphic nappe in the south. All these lithounits are characterized by a typical large Neoproterozoic population (1.05-0.80 Ga) and small fraction of the Archean and Paleoproterozoic zircon, having distinct age peaks at $\sim 2.50$ and $\sim 1.80$ Ga (Fig. 4).

Along the Sutlej valley in the western Himalaya, the GHS possesses DZ ages between 0.77 and $2.60 \mathrm{Ga}$ with peaks at $\sim 0.82$ and $2.52 \mathrm{Ga}$, like the Alaknanda valley (Figs. 4a, b; Webb et al., 2011, Spencer et al., 2012).

Incoming of the Neoproterozoic DZ of $~ 1.06 \mathrm{Ga}$ with decreasing age to $\sim 0.86 \mathrm{Ga}$ in the uppermost part is characteristics of the GHS Belt. Similar zircon distribution pattern is distinctly visible in overthrust Neoproterozoic metasediments of the Garhwal, Ramgarh and Almora nappes, where $\mathrm{U}-\mathrm{Pb}$ youngest $\mathrm{DZ}$ ages range between 0.88 and 0.81 Ga (Fig. 3; Mandal et al., 2015).

A compilation of available U-Pb DZ data from the Nepalese GHS give peak ages of $0.80-1.20,1.60-1.90$ and $2.40-2.70$ Ga with the Neoproterozoic grains making nearly half of the population (Fig. 4c; Gehrels et al. 2011). An intrusive orthogneiss of 0.47 to $0.49 \mathrm{Ga}$ within the GHS constrains its age of deposition between 0.80 and 0.50Ga (Cawood et al., 2007).

In the Sikkimese GHS, orthogneiss contains ${ }^{207} \mathrm{~Pb} /{ }^{206} \mathrm{~Pb} 829 \pm 28$ Ma zircon with inherited Paleoproterozoic cores, besides containing $604 \pm 28$ and 508 \pm 22 Ma zircon (Fig. 4d; Mottram et al., 2014). In central Bhutan, the DZ records consistent younging from 1.00 to 0.80 Ga from the base to the top with minor Paleoproterozoic peaks of 2.45 and 1.9-1.75 Ga (Fig. 4d; McQuarrie et al., 2013). Since 0.500.48 Ga plutons intrude the lower parts, deposition of the Bhutanese GHS gets bracketed between $\sim 0.50$ and younger than $0.724 \mathrm{Ga}$ (McQuarrie et al., 2013).

Further east in western Kameng and Subansiri valleys of Arunachal Himalaya, U-Pb zircon ages from orthogneiss intrusives lie between $878 \pm 12.6$ and $836.9 \pm 13.2 \mathrm{Ma}$, with younger intrusive phase ca $\sim 505$ Ma (Yin et al., 2010a). With the youngest DZ ages between 1.0 and $0.83 \mathrm{Ga}$, these intrusives constrain maximum depositional age of the GHS in western Arunachal Pradesh between 0.90 and $0.50 \mathrm{Ga}$ (Fig. 4e; Yin et al., 2010a; Webb et al., 2013). From Subansiri region, Singh et al. (2019) obtained zircon U-Pb ages between 516 and 486 Ma from peraluminous to calc-alkaline granitoids with negative $\varepsilon \mathrm{Hf}(\mathrm{t})$ values ranging from -1.4 to -12.7 and yield crustal Hf model ages from 1.5 to $2.2 \mathrm{Ga}$, suggesting the occurrence of a major crustal growth event in the Proterozoic and re-melting of the crust during the early Paleozoic. Along the Siyom valley above the MCT, high-grade GHS yielded U-Pb DZ ages between 0.81 to $2.0 \mathrm{Ga}$ (Fig. 4f); the Neoproterozoic ( 810 Ma) maximum depositional age is constrained from the adjoining $809 \pm 4.5$ Ma orthogneiss (Clarke et al., 2016).

\section{Tethyan Himalayan Sequence (THS)}

The Haimanta Formation of the THS in the Chandra Valley

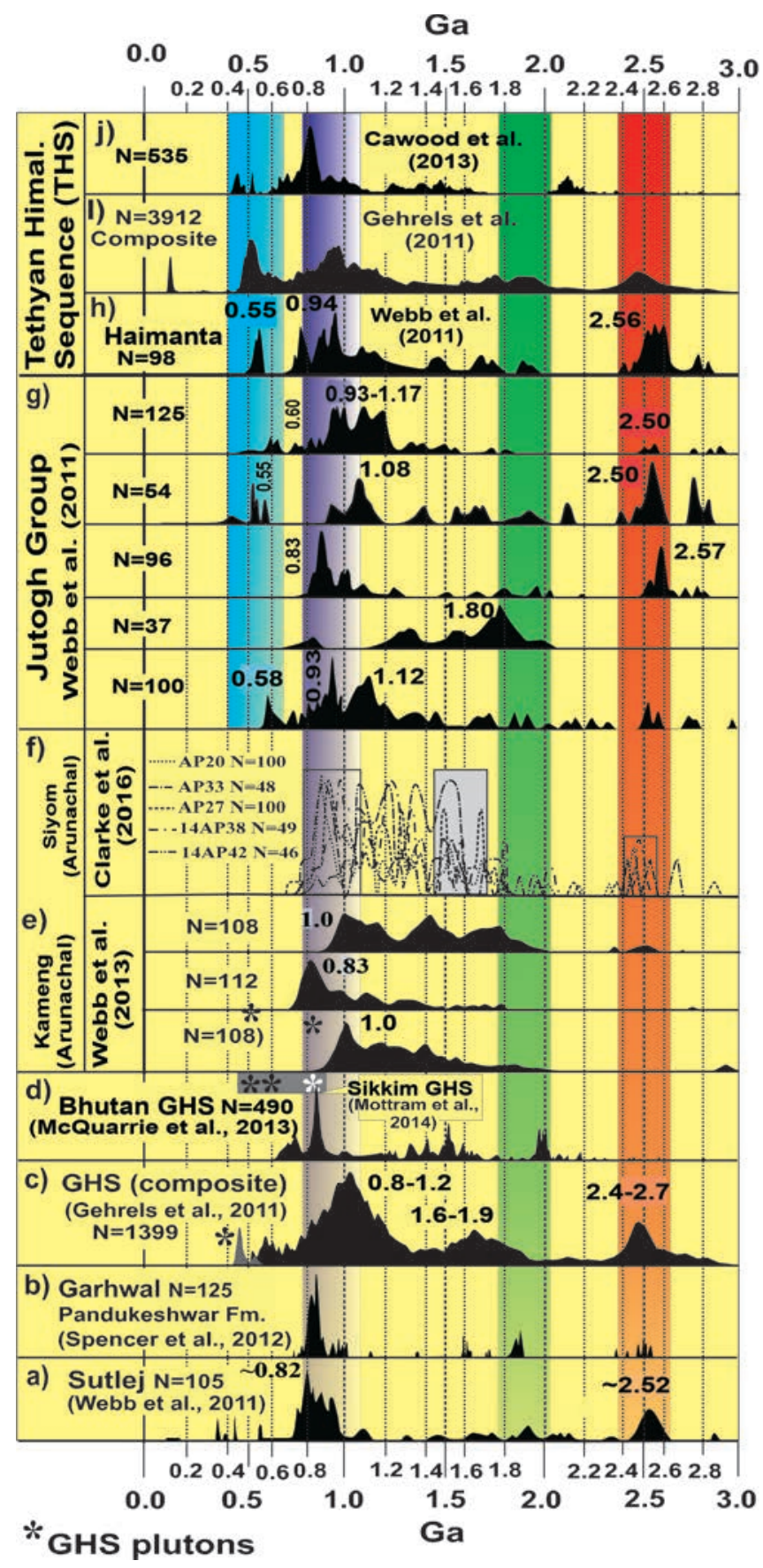

Figure 4. Probability distribution plots of the $\mathrm{U}-\mathrm{Pb}$ zircon ages from the Great Himalayan Sequence (GHS) and their comparison with the Jutogh Group and the Tethyan Himalayan Sequence (THS). Common distribution of $2.5 \mathrm{Ga}, 2.0-1.8$ and 1.0-0.85 Ga zircon areshown by vertical columns, while the Paleozoic zircon appear in the Jutogh Group and the THS. Data sources in parenthesis (see references). ' $n$ '=number of the $U$-Pb zircon analyses. 
(Himachal Pradesh) yielded DZ pattern of grains between 0.55 and 3.0 Ga with additional peaks of $\sim 0.94$ and 2.56 Ga (Fig. 4h). Between the Beas-Sutlej-Pabbar valleys, the Jutogh and Chail Formations have broadly the same DZ age distribution with peaks of $\sim 0.55, \sim 0.95$, $\sim 2.55 \mathrm{Ga}$ and older grains (Fig. 4g; Webb et al., 2011). Distribution of the DZ population bears strong similarities with the THS zircon (Figs. 4i-j; Gehrels et al., 2011; Cawood et al., 2013), and thus, provide a very powerful tool for correlation across tectonic boundaries.

In Nepal and Bhutan, Gehrels et al. (2011) noted that all the THS units from Cambrian to Cretaceous have almost similar U-Pb DZ ages, dominated by $0.48-0.57,0.75-1.20$ and $2.43-2.56$ Ga peaks (Fig. 4i). In central Bhutan, oldest Chekha Formation of the THS yielded 0.49-0.51 Ga youngest grain populations (McQuarrie et al., 2013).

\section{Paleoproterozoic tectonic set-up for the iLH}

Northern margin of the Indian Plate witnessed variable tectonic set-up since Paleoprotozoic on wards. Major crustal generation during the Paleoproterozoic are indicated by voluminous bimodal magmatism and magmatic sequences within the iLH and the MCTZ. We, therefore, treat the iLH as a separate entity in the Himalayan domain. This set-up has recently been controversial from a geosynclinal, passive or epicratonic basin. However, Kohn et al. (2010) opined that the iLH and MCTZ represent a Paleoprotezoic arc system, which developed in a very short duration ( 100 ma) only. Field evidences, geochemical discrimination diagrams and palegeographic set-up favoured an arc-type set-up (Kohn et al., 2010; also Rao and Sharma, 2011; Mandal et al., 2016; Phukon et al., 2018).

On the contrary, a continental rift set-up was argued by Sakai et al. (2013) and Larson et al. (2017), based on age and stratigraphic correlation of the Himalayan Paleoproterozoic assemblage.

This work visualizes magmatic arc set-up for unique iLH and MCTZ assemblages. Melt generation for the granotoids within the MCT zone was caused through subduction-related processes involving hydrous partial melting of a Paleoproterozoic amphibole- and/or garnet-bearing mafic source with the involvement of sediments from the subduction zone (Fig. 5). Paleoproterozoic scenario on the northern edge of the Indian Plate is more akin to an Andean-type of arc set-up (Kohn et al., 2010) and is consistent with the Columbian Supercontinent set-up during the Paleoprotezoic (Rogers and Santosh, 2002; Hou et al., 2008).

\section{Columbia Supercontinent Assembly}

Sheet-like mature iLH quartzite-volcanic association with $~ 1.90$ $\mathrm{Ga}$ U-Pb detrital zircon and the MCTZ magmatic bodies of the same age be speak in favour of proposed Proterozoic Andean-type magmatic arc (Kohn et al., 2010) back-arc system during the Columbian period (cf., Rogers and Santosh, 2002). This sedimentary sequence was deposited between 1.95 and $1.87 \mathrm{Ga}$ throughout the Himalaya with its termination around end of the Orosirian period. The arc granitoids yield tightly-clustered Paleoproterozoic zircon ages at 1.97 and 1.89 Ma, indicating almost contemporaneous sedimentation and magmatic crystallization at $\sim 1.90 \mathrm{Ga}$ (Fig. 2). The magmatic arc back-arc system possibly belongs to one of the margins of the Columbia Supercontinent (Fig.5a).

Out of different paleotectonic reconstructions for the Columbia Supercontinent, assemblies by Rodger and Santosh (2002), Zhao et al. (2004), Hou et al. (2008) and Kaur et al. (2013) are most relevant here. An Andean-type magmatic arc system on edge of this continent involves North America (NA), India (I), Madagascar, Sri Lanka and
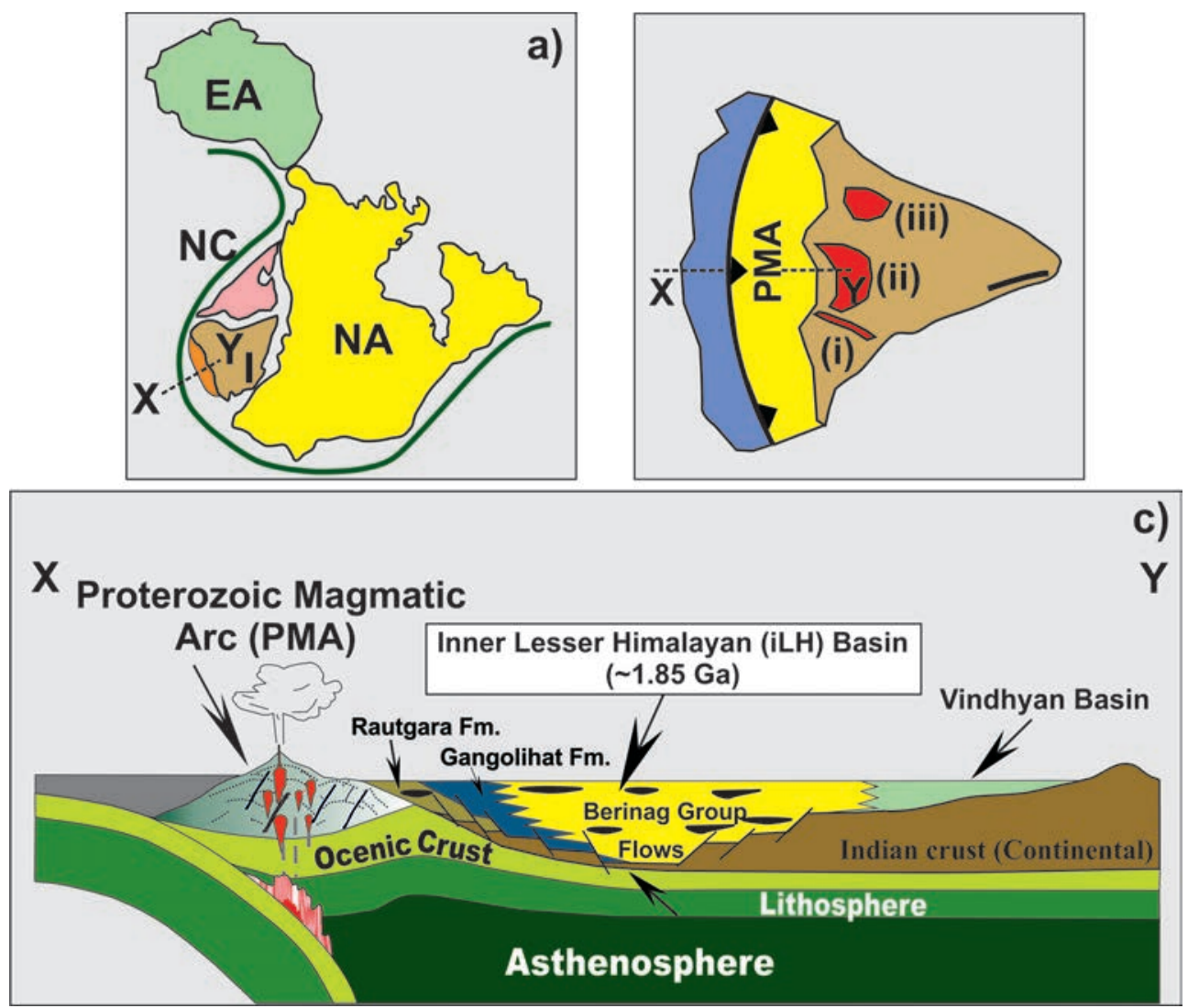

Figure 5. Columbian reconstruction ca. $1.9 \mathrm{Ga}$ with position of India and the postulated magmatic arc. a) Reconstruction after Rogers and Santosh (2002), Hou et al. (2008) and Kaur et al. (2013). NA-North America. EA-Eastern Antarctica. NC-North China. I-India. b) Position of the Proterozoic magmatic arc, its configuration of forearc (blue), backarc (yellow) and the position of India with the (i) Aravalli, (ii) Bundelkhand, and (iii) Singhbhum cratons. Cross-section along XY. c) Schematic reconstruction of the Paleoproterozoic magmatic arc and backarc basin during 2.0-1.8 Ga. Subducted and partially melted oceanic lithosphere caused emplacement of arc granitoids. The iLH belt deposited in rifted back arc basin and received sediments, both from arc and Indian craton. 
North China (NC) during the Columbia 2.06 1.78 Ga period, when deposited sediments contained detrital zircon almost of the same age (Fig. 5a). The Andean-type magmatic arc system, represented by the MCT Zone (cf., Kohn et al., 2010) - the 'Paleoproterozoic Magmatic Arc (PMA)', defines one margin of this supercontinent. The volcanosedimentary arc basin contains psammite schist and amphibolite, possibly belonging to its fore-arc and volcanic arc respectively, while intensely sheared orthomylonite represents its $\sim 1.90$ Ga plutonism. $\sim$ ca. 2.0-1.8 Ga iLH sedimentary sequence, incorporating the oldest Rautgara-Gangolihat-Berinag, their equivalents and interstratified mafic-felsic volcanics (cf., Miller et al., 2001; Richards et al., 2006), were contemporaneously deposited in the rifted back-arc basin. This evolving basin derived its detritus, both from the magmatic arc and the Indian Shield (Figs. 5b, c), and extended even into the Aravalli belt, where $\sim 1.85$ Ga subduction-related magmatism, erosion and sedimentation record contemporaneous yield of detrital zircon almost of the same age (Kaur et al., 2013). Additionally, 3.5 Ga and 2.7-2.5 Ga granitoids from the Aravalli and Bundelkhand cratons might have sourced a small component of the older zircon within the iLH.

Break-up of the Columbian supercontinent separated the Indian craton with its northern margin becoming passive one as it drifted away and reassembled to form the Rodinia Super continent during the Neoproterozoic. Thus, major part of this magmatic arc is lost and only a small part of the arc-crust remained with India. Extinct Proterozoic arc-crust and part of back-arc basin paved way for deposition of the Greater Himalayan Sequence (GHS).

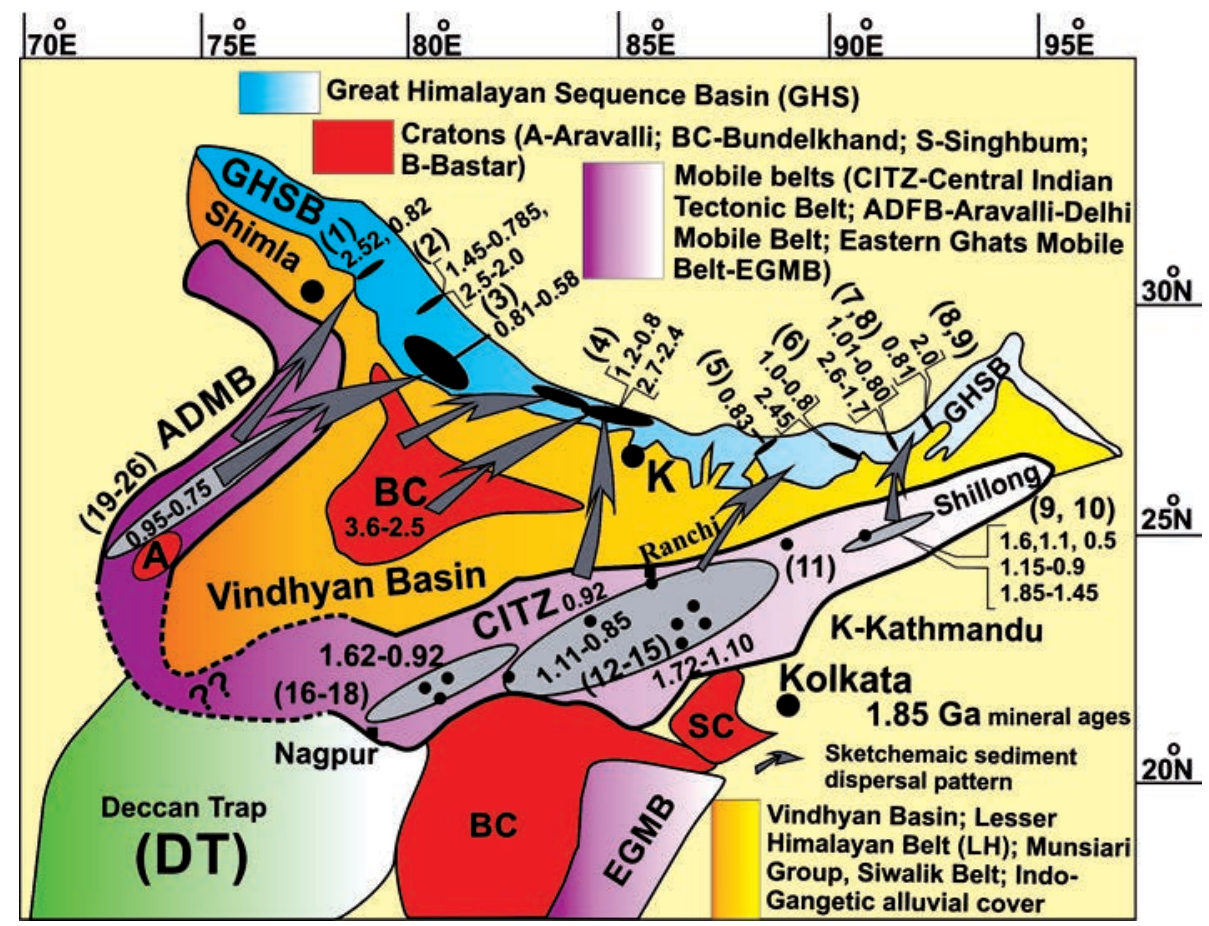

Figure 6. Source for the Neoproterozoic detrital zircon in the Great Himalayan Sequence (GHS) and correlatable successions in the Lesser Himalaya. 'In-Board' Indian cratonic sources from the ADMB (Aravalli Delhi Fold Belt) and the CITZ (Central Indian Tectonic Zone), called together as GIPFOB (Great Indian Proterozoic Fold Belt) (cf. Prabhakar et al., 2014). The GIPFOB possibly remained highland during Neoproterozoic and eroded off to provide detritus to the GHS basin. Sections 1 to 9 yielded 1.1 to 0.85 youngest detrital zircon from Himachal to Arunachal in the GHS. Data sources: Nos. 1 to 26 in references.

\section{Passive Neoproterozoic basin for the GHS and oLH}

Between the break-up of the Paleoproterozoic Columbian supercontinent and deposition of the GHS, there is no report of any paleo-tectonic reconstruction that can suggest any active margin setup for northern edge of the Indian Plate. Hence, a simple passive margin set-up for the deposition of the GHS and oLH sequences with the iLH and MCTZ as the basements (Fig. 6).

\section{Great Himalayan Sequence (GHS): 1.10- 0.85 Ga zircon}

Arrival of the Neoproterozoic 1.10-0.85 Ga detrital zircon in the GHS makes it distinct from the iLH and the MCT Zone. These zircon are omnipresent along its entire length, within the $\mathrm{LH}$ metamorphic nappes, and the oLH. In view of its paleogeographic significance during the Neoproterozoic, sediments in this basin could either be potentially derived from the following sources (Fig. 6).

\section{'Within-basin' magmatic bodies}

The $~ 1.00-0.85$ Ga DZ suite might have been sourced from intrabasinal and eroded granite belt of $\sim 0.90-0.80$ Ga isolated granite intrusives from the Chor pluton and other bodies within the Jutogh Nappe (Fig. 6; Singh et al., 2002; Webb et al., 2011). Additional $\sim 0.85$ Ga bodies within the GHS are orthogneiss in Black MountainsMansehra pluton (Pakistan), Alaknanda valley (Spencer et al., 2012), above the MCT in Sikkim (Mottram et al., 2014) and Kakhtang thrust, central Bhutan (Richards et al., 2006), mylonitized granite in Kameng and Subansiri, Arunachal (Yin et al., 2010a). Based on 860840 Ma detrital zircon ages, their enriched radiogenic Hf isotopic signatures ( $\varepsilon \mathrm{Hf}=10$ to 20$)$ and comparisons with nearby potential sources, Spencer et al. (2018) postulated an active continental margin source for these GHS detrital zircon along the northern margin. Though some relicts of this magmatism are observed within the GHS, it is likely that this source was tectonically removed during the Kurgiakh orogeny prior to accretion of the Asian continental margin (Fig. 6; Spencer et al., 2018).

\section{'In-board' Indian craton sources}

Additional possible and likely sources for the Neoproterozoic DZ may be the Indian Aravalli Delhi Mobile Belt (ADMB) and Central Indian Tectonic Zone (CITZ) (Fig. 6). In this work, it is visualized that this 'garland' of uplifted major tectonic accretionary zone, called as the Great Indian Proterozoic Fold Belt (GIPFOB) (cf., 
Prabhaker et al., 2014), was a highland mountain belt and eroded off around $\sim 1.00-0.90 \mathrm{Ga}$.

\section{Aravalli Delhi Mobile Belt (ADMB)}

In the ADMB, widespread Neoproterozoic magmatic bodies extend from the Tosham (Haryana) to Balaram (Gujarat): Ojhar Granite (>960 Ma), Newania carbonatite (955 $\pm 24 \mathrm{Ma})$, Erinpura granite (990 and $830 \mathrm{Ma}$ ) and Mt. Abu granitoid (800-730 Ma) (Just et al., 2011; Van Lente et al., 2009; Pradhan et al., 2010; Ashwal et al., 2013; Pandit, personal communication). U-Pb zircon ages of $987 \pm 6.4$ and 986.3 \pm 2.4 Ma from the Ambaji-Sendra rhyolites reveal presence of an extensive arc terrane on western flank of the ADMB in its southern and northern parts (Deb et al., 2001, 2004). In the southern part of the Ambaji-Sendra belt, a U-Pb zircon age of 836+7/-5 Ma for the Siwaya gneissic granite matches the felsic Erinpura plutons that have intruded the arc sequence (Deb et al., 2001). The other granitoids such as the Sendra-Ambaji granite (840-760 Ma), the Dudhi Sendra granites (850-900 Ma) are intrusives in the Delhi metasediments (Choudhary et al., 1984), and evolved due to partial melting of underlying granite-gneiss crust (Tobish et al., 1994). Thus, geochronological data from the ADMB on sediments and intercalated volcanics between 1240 and 966 Ma (Deb et al., 2001), plagiogranite intrusions at $1015 \pm 4.4 \mathrm{Ma}$ (Dharma Rao et al., 2013) and calc-alkaline granitoids at $968 \pm 1 \mathrm{Ma}$ (Pandit et al., 2003) record the evolution of a Neoproterozoic volcanic arc between the Marwar terrane and AravalliBundelkhand craton of the NW Indian shield.

\section{Central Indian Tectonic Zone (CITZ)}

The CITZ documents widespread felsic plutonism, acid and bimodal volcanism, which were associated with different tectonothermal events between 2.2 and 0.50 Ga (Fig. 6; Mishra, et al., 2000; Roy and Hanuma Prasad, 2003; Rekha, et al., 2011; Bhowmik, et al., 2012). In the present context, synkinematic Neoproterozoic ca. 1.2-0.9 Ga granitoids intruded basement gneiss within the Sausar fold belt of the CITZ along the Gavilgarh-Tan Shear Zone (Chattopadhyay et al., 2017) and adjacent the Sausar and Bilaspur-Raigarh belts (Roy and Hanumana Prasad, 2003). In southern parts of the belt, Maji et al. (2008) noted an association of expansive granitoids with early Neoproterozoic (1.0-0.9 Ga) prograde amphibolite-facies metamorphism.

Further east within the CITZ, the Chotanagpur Granite Gneissic Complex (CGGC) exposes numerous syncollisional granitoids into older anatectic gneiss where WR Rb-Sr isochron ages vary between $1005 \pm 51$ Ma and 815 \pm 47 Ma (Pandey et al., 1986a, b, 1995; Mallick, 1993; Krishna et al., 1996). These granitoids appear to be part of an extensive Neoproterozoic granite belt and might be associated with high-grade $\sim 1.0$ Ga metamorphic terranes in northeast and northcentral CGGC (Chatterjee and Ghose, 2011). It appears to be linked to the North Singhbhum Mobile Belt (NSMB) convergence with the CGGC, where postulated northward oceanic subduction caused the emplacement of such plutons (Rekha et al., 2011).

Further, Neoproterozoic accretionary phase in the GIPFOB coincided with the $1.0 \mathrm{Ga}$ 'rhyolite flare-up' in the Peninsular India and felsic tuff deposits between 1.0 and 0.9 Ga in the Upper Vindhyan, the Chhattisgarh/Khariar and the Indravati basins (Patranabis-Deb, et al. 2007; Malone, et al. 2008; Bickford, et al. 2011a, b; Gopalan et al. 2013). Bickford et al. (2011a) linked this flare-up to collision between East Antarctica and India, and suturing of North and South Indian craton blocks along the CITZ during the Rodinia assembly.

Across the Brahmaputra valley in Shillong plateau and Mikir hills, $\mathrm{U}-\mathrm{Pb}$ zircon geochronology of numerous granitoids yielded ${ }^{207} \mathrm{~Pb} /$ ${ }^{206} \mathrm{~Pb}$ weighed mean ages between 1.15 and $0.95 \mathrm{Ga}$ within an older phase and younger early Paleozoic events (Yin et al., 2010). These events were possibly related to the arc development and subsequent continental collision to evolve the proto-Indian continent.

\section{External ‘Out-board’ terranes}

The Neoproterozoic sediments of the GHS basin were sourced from adjoining continents (Nubian-Arabia, Africa, Madagascar, eastern Antarctica, Australia) during the Rodinia Supercontinent assembly (DeCelles et al., 2000; Myrow et al., 2010; Spencer et al., 2012a). Such an 'Out-Board' detrital source was eroded off, while long paleo-river systems transported these over long distances across the Indian craton. These paleo-rivers would have brought detritus dominantly from the Archean Paleoproterozoic terranes with insignificant contributions from the Neoproterozoic domains. On the contrary, reverse is observed in the GHS zircon population.

\section{Conclusions}

$\mathrm{U}-\mathrm{Pb}$ zircon ages of lithounits on either side of the Main Central Thrust Zone (MCTZ) and their regional correlations within the Himalaya provide us valuable data to distinguish terranes, possessing the following characters.

i) The Berinag Group quartzite and Rampur/Daling/Shumar Groups of the Inner Lesser Himalaya (iLH) sedimentary belt contain detrital zircon (DZ)U-Pb population of 2.05 to 1.80 Ga age, and a minor Neoarchean-Early Proterozoic component (2.60 to 2.20 Ga). The overthrust MCTZ sequence (Munsiari Group orthomylonite/Ulleri mylonite etc.) contains tightly-clustered Paleoproterozoic magmatic zircon between 1.95 and $1.89 \mathrm{Ga}$. These two lithotectonic units represents a major Paleoproterozoic magmatic arc-back-arc sequence of the Columbia Supercontinent assembly for a short duration of about 60 my. Detrital zircon in the iLH are derived, both from the Archean-Proterozoic Aravalli-Bundelkhand nuclei of the Indian craton and the $1.90 \mathrm{Ga}$ magmatic arc, and markedly differs from the Outer Lesser Himalayan (oLH) sedimentary belt, which is characterized by 0.95 to $0.525 \mathrm{Ga}$ younging detrital zircon, synchronous with the Paleozoic magmatism in the source.

ii) The overthrust Great Himalayan Sequence (GHS) is markedly different across the MCTZ Munsiari/Ramgarh Groups, with first arrival of the Neoproterozoic 1.05-0.85 Ga detrital zircon. These zircon grains first started appearing in its basal sequences with small population of $1.00 \mathrm{Ga}$ grains. In conformably overlying sequences, the Neoproterozoic zircon predominate among the older clusters and become somewhat younger to $0.965-0.860 \mathrm{Ma}$ in the youngest parts near the South Tibetan Detachment System (STDS). Minor presence of the Neoarchean-Early Proterozoic zircon continue in this sequence, indicating that both the MCTZ and iLH were possibly eroded off during the Neoproterozoic along with the Indian craton.

iii) The oldest sequences in the Tethyan Himalayan Sequence 
(THS) are marked by 0.55 and 0.48 Ga youngest zircon population at the start of the Tethyan sedimentation with an unconformity, when the Paleozoic granitoids and the GHS were eroded off to shed detritus to this basin.

iv) Source rocks for predominant Neoproterozoic zircon population in the GHS remains controversial: extreme sediment transport from 'Off-board' terranes vs. 'In-board' sources. Our preferred models for the $\sim 1.05-0.85$ Ga Tonian detrital zircon in the GHS is the erosion of an extensive Neoproterozoic magmatic belt/arc in northern proximity of the GHS basin on fringe of the Rodinia Supercontinent. Likely vestiges of this magmatic belt are the presence of numerous small granitoid bodies throughout the GHS. This magmatic belt was active, uplifted and eroded off during the Neoproterozoic to deposit the GHS sediments. The other 'Inboard' source from the Aravalli-Delhi Fold Belt (ADMB) and the Central Indian Tectonic Zone (CITZ) makes these belts uplifted mountains, which were eroded off during the Neoproterozoic, bringing the detritus to the GHS basin from the southern terranes.

\section{Acknowledgements}

The authors are indebted to Dr. F. Fareeduddin, Chief Editor of the Episodes special volume for inviting the authors for this contribution. The Indian National Science Academy (INSA) has extended the Senior and Honorary Scientist positions to AKJ, which facilitated this research at the CSIR-Central Building Research Institute, Roorkee. M.K. Pandit has provided invaluable data and inputs for the Aravalli belt. Discussions with O.N. Bhargava, I.B. Singh, D.M. Banerjee, D.C. Srivastava, J.K.Pati, N.C. Pant and M. Joshi were extremely useful in clarifying sedimentary distribution system in the Himalaya. Erudite comments by M. Joshi, R.K. Srivastava and RK Bikramaditya Singh are extremely useful in revising the manuscript.

\section{References}

Ashwal, L.D., Solanki, A.M., Pandit, M.K., Corfu, F., Hendriks, B.W.H., Burke, K., Torsvik, T.H., 2013, Geochronology and geochemistry of Neoproterozoic Mt. Abu Granitoids, NW India: Regional correlation and implications for Rodinia paleogeography. Precambrian Research,v. 236, pp. 265-281. [26]

Bhargava, O.N., Srikantia, S.V., 2014, Geology and age of metamorphism of the Jutoghand Vaikrita Thrust Sheets, Himachal Himalaya. Himalayan Geology, v. 35(1), pp. 1-15.

Bhowmik, S.K., Wilde, S.A., Bhandari, A., Pal, T., Pant, N.C., 2012, Growth of the greater Indian landmass and its assembly in Rodinia: geochronological evidence from the central Indian tectonic Zone. Gondwana Research, v. 22, pp. 54-72. [18]

Bickford, M.E., Basu, A., Mukherjee, A., Hietpas, J., Schieber, J., Patranabis-Deb, S., Ray, R., Guhey, R., Bhattacharya, P., Dhang, P., 2011a, New U-Pb SHRIMP zircon ages of the Dhamda Tuff in the Mesoproterozoic Chhattisgarh Basin, peninsular India: stratigraphic implications and significance of a 1 Ga thermalmagmatic event. Journal of Geology, v. 119, pp. 535-548.

Bickford, M.E., Basu, A., Patranabis-Deb, S., Dhang, P.C., Schieber, J., 2011b, Depositional history of the Chhattisgarh Basin, central India: constraints from new SHRIMP zircon ages. Journal of Geology, v. 119, pp. 33-50.
Bikramaditya Singh, R.K., SINGHA.K., Chung S.-L., Sharma R., Lee H.-Y., 2019. Zircon U-Pb ages and Lu-Hf isotopes of metagranitoids from the Subansiri region, Eastern Himalaya: implications for crustal evolution along the northern Indian passive margin in the early Paleozoic. In Sharma R., Villa I.M., Kumar S. (Eds.), Crustal Architecture and Evolution of the Himalaya-Karakoram-Tibet Orogen. Geological Society, London, Special Publication 481, doi.org/10.1144/SP481.7.

Cawood, P.A., Johnson, M.R.W.,Nemchin, A.A., 2007. Early Paleozoic orogenesis along the Indian margin of Gondwana: tectonic response to Gondwana assembly. Earth and Planetary Science Letters 255, 70-84.

Célérier, J., Harrison, T.M., Webb, A.A., Yin. A., 2009. The Kumaun and Garhwal Lesser Himalaya, India. Part 1. Structure and stratigraphy. Geological Society of America Bulletin 121, 12621280. [3]

Chatterjee, N., Ghose, N.C., 2011. Extensive Early Neoproterozoic high-grade metamorphism in North Chotanagpur Gneissic Complex of the Central Indian Tectonic Zone. Gondwana Research 20, 362-379. [11]

Chattopadhyay, A., Chatterjee, A, Das, K., Sarkar, A., 2017. Neoproterozoic transpression and granite magmatism in the Gavilgarh-Tan Shear Zone, central India: Tectonic significance of $\mathrm{U}-\mathrm{Pb}$ zircon and $\mathrm{U}-\mathrm{Th}$ total $\mathrm{Pb}$ monazite ages. Journal of Asian Earth Sciences 147, 485-501. [17]

Clarke, G.L., Bhowmik, S.K., Ireland, T.R., Aitchison, J.C., Chapman, S.L., Kent, L., 2016. Inverted Oligo-Miocene metamorphism in the Lesser Himalaya Sequence, Arunachal Pradesh, India; age and grade relationships. Journal of Metamorphic Geology 34, 805-820. doi:10.1111/jmg.12202.

Choudhary, A.K., Gopalan, K., Sastry, C.A., 1984. Present status of the geochronology of the Precambrian rocks of Rajasthan: Tectonophysics, v. 105(1-4), p. 131-140. [22]

Deb, M., Thorpe, R.I., 2004. Geochronological constraints in the Precambrian Geology of Rajasthan and their Metallogenic Implications. In Deb, M., Gooffellow, W.D., (Eds.). Sedimenthosted Lead-Zinc Sulphide Deposits. Narosa Publishing House, New Delhi, India, 246-263. [21]

Deb, M., Thorpe, R.I., Kristic, D., Corfu, F., Davis, D.W., 2001. Zircon $\mathrm{U}-\mathrm{Pb}$ and Galena $\mathrm{Pb}$ isotope evidence for an approximate 1.0 Ga terrane constituting the western margin of the Aravalli-Delhi orogenic belt, northwestern India. Precambrian Research 108, 195-213. [20]

DeCelles, P.G., Gehrels, G.E., Najman, Y., Martin, A.J., Carter, A., Garzanti, E., 2004. Detrital geochronology and geochemistry of Cretaceous-Early Miocene strata of Nepal: Implications for timing and diachroneity of initial Himalayan orogenesis. Earth and Planetary Science Letters 227, 313-330, doi: 10.1016/j. epsl.2004.08.019.

DeCelles, P.G., Gehrels, G.E., Quade, J., LaReau, B., Spurlin, M., 2000. Tectonic implications of U-Pb zircon ages of the Himalayan orogenic belt in Nepal. Science 288, 497-499. [4]

DeCelles, P.G., Robinson, D.M., Quade, J., Ojha, T.P., Garzione, C.N., Copeland, P., Upreti, B.N., 2001. Stratigraphy, structure, and tectonic evolution of the Himalayan fold-thrust belt in western Nepal. Tectonics 20, 487-509

Dharma Rao, C.V., Santosh, M., Kim, S.W., Li, S., 2013. Arc magmatism in the Delhi Fold Belt: SHRIMP U-Pb zircon ages of granitoids and implications for Neoproterozoic convergent margin tectonics in NW India. Journal of Asian Earth Sciences 78, 83-99.

Gehrels, G.E., 2011, Detrital zircon U Pb geochronology: Current methods and new opportunities. In: Busby, C., and Perez, A.A.(Eds.), Tectonics of Sedimentary Basins: Recent Advances. 
Wiley Blackwell, Hoboken, N.J., 47-62. [4]

Gehrels, G.E., 2014. Detrital Zircon U-Pb Geochronology Applied to Tectonics. Annual Review of Earth and Planetary Sciences 42, 127-149, doi.org/10.1146/annurev-earth-050212-124012.

Gehrels, G.E., Kapp, P., DeCelles, P., Pullen, A., Blakey, R., Weislogel, A., Ding, L., Guynn, J., Martin, A., McQuarrie, N., Yin, A., 2011. Detrital zircon geochronology of pre Tertiary strata in the Tibetan Himalayan orogen. Tectonics, v. 30, p. TC5016, doi:10.1029/ 2011 TC002868.

Gehrels, G.E., Valencia, V.A., Ruiz, J., 2008. Enhanced precision, accuracy, efûciency, and spatial resolution of U-Pb ages by laser ablation-multicollector-inductively coupled plasma-mass spectrometry. Geochemistry Geophysics Geosystems 9(3), Q03017, doi: 10.1029/2007GC001805.

Gopalan, K., Kumar, A., Kumar, B., Vijayagopal, B., 2013. Depositional history of the Upper Vindhyan succession, central India: time constraints from $\mathrm{Pb}-\mathrm{Pb}$ isochron ages of its carbonate components. Precambrian Research 233, 108-117.

Hodges, K.V., 2000. Tectonics of the Himalaya and southern Tibet from two perspectives. Geological Society of America Bulletin 112 (3), 324-350.

Hofmann M., Linnemann, U., Rai, V., Becker, S., Gärtner, A.,Sagawe, A., 2011. The India and South China cratons at the margin of Rodinia-Synchronous Neoproterozoic magmatism revealed by LA-ICP-MS zircon analyses. Lithos 123, 176-187.

Hou, G., Santosh, M., Qian, X., Lister, G.S. Li, J., 2008. Configuration of the Late Paleoproterozoic supercontinent Columbia: Insights from radiating mafic dyke swarms. Gondwana Research 14, 395409.

Jain, A.K., Shrestha, M., Seth, P., Kanyal, L., Carosi, R., Montomoli, C., Iaccarino, S., Mukherjee, P.K., 2014. The Higher Himalayan Crystallines, Alaknanda - Dhauli Ganga Valleys, Garhwal Himalaya, India. In Montomoli, C., Carosi, R., Law, R.D., Singh, S., and Rai, S.M. (Eds.), Geological field trips in the Himalaya, Karakoram and Tibet. Journal of Virtual Explorer, Electronic Edition 47 paper 8, ISSN 1441-8142.

Just, J, Schulz, B, de Wall, H, Jourdan F, Pandit, M K., 2011. Monazite CHIME/EPMA dating of granitoid deformation: implications for Neoproterozoic tectono-thermal evolution of NW India. Gondwana Research 19, 402-412. [19]

Kaur, P., Zeh, A., Chaudhri, N., Gerdes, A., Okrusch, M., 2013. Nature of magmatism and sedimentation at a Columbia active margin: insights from combined $\mathrm{U}-\mathrm{Pb}$ and $\mathrm{Lu}-\mathrm{Hf}$ isotope data of detrital zircon from NW India. Gondwana Research 23(3) 1040-1052, doi:10.1016/j.gr.2012.07.008. [22]

Khanal, S., Robinson, D.M., Mandal, S.Simkhada, P., 2015. Structural, geochronological and geochemical evidence for two distinct thrust sheets in the "Main Central thrust zone", the Main Central thrust and Ramgarh-Munsiari thrust: Implications for upper crustal shortening in the central Nepal.In Mukherjee, S., Carosi, R., van der Beek, P.A., Mukherjee, B.K. Robinson, D.M. (Eds.), Tectonics of the Himalaya. Geological Society, London, Special Publication 412, 221-245, doi:10.1144/SP412.2. [4]

Kohn, M.J., Paul, S.K. Corrie, S.L., 2010. The lower Lesser Himalayan sequence: a Paleoproterozoic arc on the northern margin of the Indian plate. Geological Society of America Bulletin 122, 323-335. [4]

Krishna, V., Prasad, R.N., Pandey, U.K., Chabria, T., Saxena, V.P., 1996. Rb-Sr geochronology of Chhotanagpur gneiss granulite complex around Kailashnathgufa area, Raigarh district, M.P. In Proceedings, National Symposium on Mass Spectrometry, VIIth, Gwalior, Indian Society of Mass Spectrometry, Defence Research and Development Establishment, 445-447.

Larson, K., Piercey, S., Cottle, J., 2017. Preservation of a
Paleoproterozoic rifted margin in the Himalaya: Insight from the Ulleri-Phaplu-Melung orthogneiss. Geoscience Frontiers, 1-13. http://dx.doi.org/10.1016/j.gsf.2017.05.010.

Long, S., McQuarrie, N., Tobgay, T., Rose, C., Gehrels, G., Grujic, D., 2011. Tectonostratigraphy of the Lesser Himalaya of Bhutan: implications for the along-strike stratigraphic continuity of the northern Indian margin. Geological Society of America Bulletin, v. 123, p. 1406-1426. [6]

Maji, A.K., Goon, S., Bhattacharya, A., Mishra, B., Mahato, S., Bernhardt, H.J., 2008. Proterozoic polyphase metamorphism in the Chhotanagpur gneissic complex (India), and implication for trans-continental Gondwanaland correlation. Precambrian Research, 162, 385-402. [15]

Mallick, A.K., 1993. Dating of granite plutons in Bihar mica belt, Bihar. Records of the Geological Survey of India 126 (2), 27-29.

Malone, S., Meert, J., Banerjee, D.M., Pandit, M., Tamrat, E., Kamenov, G.D., Pradhan, V., Sohl, L.E., 2008. Paleomagnetism and detrital zircon geochronology of the Upper Vindhyan Sequence, Son Valley and Rajasthan, India: a ca. 1000 Ma closure age for the Purana Basins?. Precambrian Research 164, 137-159.

Mandal, S., Robinson, D.M., Khanal, S., Das, O., 2015. Redefining the tectonostratigraphic and structural architecture of the Almora klippe and the Ramgarh-Munsiari Thrust sheet in NW India. In Mukherjee, S., Carosi, R., van der Beek, P.A., Mukherjee, B.K., Robinson, D.M.(Eds.), Tectonics of the Himalaya: Geological Society, London, Special Publication 412, 247-269. [3]

Mandal, S., Robinson, D.M., Kohn, M.J., Khanal, S, Das, O., Bose. S., 2016. Zircon U-Pb ages and Hf isotopes of the Askot klippe, Kumaun, northwest India: Implications for Paleoproterozoic tectonics, basin evolution and associated metallogeny of the northern Indian cratonic margin. Tectonics, 35, 965-982. doi:10.1002/2015TC004064. [3]

Martin, A.J., Burgy, K.D., Kaufman, A.J., Gehrels, G.E., 2011. Stratigraphic and tectonic implications of field and isotopic constraints on depositional ages of Proterozoic Lesser Himalayan rocks in central Nepal. Precambrian Research 185 1-17. [4]

Martin, A.J., DeCelles, P.G., Gehrels, G.E., Patchett, P.J., Isachsen, C., 2005. Isotopic and structural constraints on the location of the Main Central thrust in the Annapurna Range, central Nepal Himalaya. Geological Society of America Bulletin 117, 926-944.

McKenzie, N.R., Hughes, N.C., Myrow, P.M., Xiao, S., Sharma, M., 2011. Correlation of Precambrian-Cambrian sedimentary successions across northern India and the utility of isotopic signatures of Himalayan lithotectonic zones. Earth and Planetary Science Letters 312(3), 471-483, doi:10.1016/ j.epsl.2011.10.027.[3]

McQuarrie N., Long, S., Tobgay, T., Nesbit, J.N., Gehrels, G., Ducea, M.N., 2013. Documenting basin scale, geometry and provenance through detrital geochemical data: Lessons from the Neoproterozoic to Ordovician Lesser, Greater, and Tethyan Himalayan strata of Bhutan. Gondwana Research 23, 1491-1510.

McQuarrie, N., Robinson, D.M., Long, S., Tobgay, T., Grujic, D., Gehrels, G.E., Ducea, M., 2008. Preliminary stratigraphic and structural architecture of Bhutan: implicationsfor the along strike architecture of the Himalayan system: Earth and Planetary Science Letters 272, 105-117, doi:10.1016/j.epsl.2008.04.030. [6]

Miller, C., Klotzli, U., Frank, W., Thoni, M., Grasemann, B., 2000. Proterozoic crustal evolution in the NW Himalaya (India) as recorded by circa $1.80 \mathrm{Ga}$ mafic and $1.84 \mathrm{Ga}$ granitic magmatism. Precambrian Research103, 191-206.

Mishra, D., Singh, B., Tiwari, V.M., Gupta, S.B., Rao, M.B.S.V., 2000. Two cases of continental collision and related tectonics during the Proterozoic period in India: insight from gravity modelling constrained by seismic and magnetotelluric studies: 
Precambrian Research 99, 149-169.

Mottram, C.M., Argles, T.W., Harris, N.B.W., Parrish, R.R., Horstwood, M.S.A., Warren, C.J., Gupta, S., 2014. Tectonic interleaving along the Main Central Thrust, Sikkim Himalaya. Journal of the Geological Society of London, 171, 255-268. doi.org/10.1144/jgs2013-064. [5]

Mukherjee, P.K., Singhal, S., Adlakha, V., Rai, S.K., Dutt, S., Kharya, A., Gupta, A.K., 2017, In situ U-Pb zircon micro-geochronology of MCT zone rocks in the Lesser Himalaya using LA-MC-ICPMS technique. Current Science, 112 802-810.

Myrow, P.M., Hughes, N.C., Goodge, J.W., Fanning, C.M., Williams, I.S., Peng, S.C., Bhargava, O.N., Parcha, S.K., Pogue, K.R., 2010. Extraordinary transport and mixing of sediment across Himalayan central Gondwana during the Cambrian-Ordovician: Geological Society of America Bulletin 122, 1660-1670. [3]

Myrow, P.M., Hughes, N.C., Paulsen, T.S., Williams, I.S., Parcha, S.K., Thompson, K.R., Bowring, S.A., Peng, S.-C., Ahluwalia, A.D., 2003. Integrated tectonostratigraphic reconstruction of the Himalaya and implications for its tectonic reconstruction. Earth and Planetary Science Letters 212, 433-441. [3]

Pandey, B.K., Chabria, T., Gupta, J.N., 1995. Geochronological characterisation of the Proterozoic terrains of Peninsular India: relevance to the first order target selection for uranium exploration. Exploration and Research for Atomic Minerals 8, 187-213.

Pandey, B.K., Gupta, J.N., Lall, Y., 1986a. Whole rock and Rb-Sr isochron ages for the granites from Bihar mica belt of Hazaribagh, Bihar, India. Indian Journal of Earth Sciences 12, 157-162. [14]

Pandey, B.K., Upadhyaya, L.D., Sinha, K.K., 1986b. Geochronology of Jajawal-Binda-Nagnaha granitoids in relation to uranium mineralisation. Indian Journal of Earth Sciences 13, 163-168. [14]

Pandit, M.K., Carter, L.M., Ashwal, L.D., Tucker, R.D., Torsvik, T.H., Jamtveit, B., Bhushan, S.K., 2003. Age, petrogenesis and significance of $1 \mathrm{Ga}$ granitoids and related rocks from the Sendra area, Aravalli Craton, NW India. Journal of Asian Earth Sciences 22, 363-381. [21]

Parrish, R.R., Hodges, K.V., 1996. Isotopic constraints on the age and provenance of the Lesser and Greater Himalayan sequences, Nepalese Himalaya. Geological Society of America Bulletin 108, 904-911. doi: 10.1130/0016-7606(1996)108<0904:ICOTAA> 2.3.CO;2.

Pathak M., Kumar S., 2019. Petrology, geochemistry and zircon U$\mathrm{Pb}-\mathrm{Lu}-\mathrm{Hf}$ isotopes of Paleoproterozoic granite gneiss from Bomdila in the western Arunachal Himalaya, Northeast India. In Sharma R., Villa I.M., Kumar S. (Eds.), Crustal Architecture and Evolution of the Himalaya-Karakoram-Tibet Orogen. Geological Society, London, Special Publication 481, doi.org/10.1144/ SP481-2017-169.

Patranabis-Deb, S., Bickford, M. E., Hill, B., Chaudhuri, A.K., Basu, A., 2007. SHRIMP ages of zircon in the uppermost tuff in Chattisgarh Basin in central India require $~ 500$ Ma adjustment in Indian Proterozoic stratigraphy. Journal of Geology 115, 407415.

Prabhakar, N., Bhattacharya, A., Sathyanarayanan, M., Mukherjee, P.K., 2014. Structural, Petrological, and Chronological Constraints from Eastern India and Implications for the $\sim 1.0 \mathrm{Ga}$ Assembly of Greater India. Journal of Geology 122, 411-432. [16]

Pradhan, V.R., Meert, J.G., Pandit, M.K., Kamenova G., Gregory, L.C.,Malone, S.J. 2010 India's changing place in global Proterozoic reconstructions: A review of geochronologic constraints and paleomagnetic poles from the Dharwar, Bundelkhand and Marwar cratons. Journal of Geodynamics 50, 224-242. [24]
Purohit, R., Papineau, D., Kröner, A., Sharma, K.K., Roy, A.B., 2012. Carbon isotope geochemistry and geochronological constraints of the Neoproterozoic Sirohi Group from northwest India. Precambrian Research 220-221, 80-90.[23]

Rao, D.R., Sharma, R., 2011.Arc magmatism in eastern Kumaun Himalaya, India: A study based ongeochemistry of granitoid rocks. Island Arc, v.20, 500-519.

Rekha, S., Upadhyay, D., Bhattacharya, A., Kooijman, E., Goon, S., Mahato, S., Pant, N.C., 2011. Lithostructural and chronological constraints for tectonic restoration of Proterozoic accretion in the eastern Indian Precambrian shield. Precambrian Research 187, 313-333.[12]

Richards, A., Argles, T., Harris, N., Parrish, R., Ahmad, T., Darbyshire, F., Draganits, E., 2005. Himalayan architecture constrained by isotopic tracers from clastic sediments. Earth and Planetary Science Letters 236, 773-796. [6]

Richards, A., Parrish, R., Harris, N., Argles, T., Zhang, L., 2006. Correlation of lithotectonic units across the eastern Himalaya, Bhutan. Geology 34, 341-344.

Rogers, J.J.W., Santosh, M., 2002. Configuration of Columbia, a Mesoproterozoic supercontinent. Gondwana Research 5, 5-22.

Roy, A., Prasad, H., 2003. Tectonothermal events in Central Indian Tectonic Zone (CITZ) and its implications in Rodinian crustal assembly. Journal of Asian Earth Sciences 22, 115-129.

Sakai, H., Iwano, H., Danhara, T., Takigami, Y., Rai, S.M., Upreti, B.N., Hirata, T., 2013. Rift related origin of the Paleoproterozoic Kuncha Formation, and cooling history of the Kuncha nappe and Taplejung granites, eastern Nepal Lesser Himalaya: a multi chronological approach. Island Arc 22, 338-360. http://dx.doi.org/ 10.1111/iar. 12021.

Singh, S., Barley, M.E., Brown, S.J., Jain, A.K., Manickavasagam, R.M., 2002. SHRIMP U-Pb in zircon geochronology of the Chor granitoid: evidence for Neoproterozoic magmatism in the Lesser Himalayan granite belt of NW India. Precambrian Research 118, 285-292. [1]

Singh, S., Jain, A.K., Barley, M.E., 2009. SHRIMP U-Pb c. 1860 Ma anorogenic magmatic signatures from the NW Himalaya: implications for Palaeoproterozoic assembly of the Columbia Supercontinent. In Reddy, S.M., Mazumdar, R., Evans, D.A.D., Collins, A.S. (Eds.), Palaeoproterozoic Supercontinents and Global Evolution. Geological Society, London, Special Publication 323, 283-300.

Spencer, C.J., Dyck, B., Mottram, C.M., Roberts, N.M. W., Wei-Hua Y., Martin, E.L., 2018. Deconvoluting the pre-Himalayan Indian margin - Tales of crustal growth and destruction. Geoscience Frontiers. https://doi.org/10.1016/j.gsf.2018.02.007.

Spencer, C.J., Harris, R.A., Dorais, M.J., 2012. Depositional provenance of the Himalayan metamorphic core of Garhwal region, India: Constrained by $\mathrm{U}-\mathrm{Pb}$ and $\mathrm{Hf}$ isotopes in zircon. Gondwana Research 22, 26-35. [2]

Spencer, C.J., Kirkland, C.L., Taylor, R.J., 2016. Strategies towards statistically robust interpretations of in situ U-Pb zircon geochronology. Geoscience Frontiers 7(4), 581-589.

Srikantia, S.V., Bhargava, O.N., 1998. Geology of Himachal Pradesh. Memoir Geological Society of India, 406.

Tobisch, O.T., Collerson, K.D., Bhattacharya, T., Mukhopadhyay, D., 1994. Structural relationship and Sm-Nd isotope systematic of polymetamorphic granitic gneisses and granitic rocks from central Rajasthan, India-implications for evolution of the Aravalli craton. Precambrian Research 65, 319-339.

Trivedi, J.R., Gopalan, K., Valdiya, K.S., 1984.Rb-Sr ages of granitic rocks within the Lesser Himalayan Nappes, Kumaun, India. Journal of Geological Society of India 25, 641-654.

Valdiya, K.S., 1980. Geology of the Kumaun Lesser Himalaya. Wadia 
Institute of Himalayan Geology, Dehra Dun India, 291.

van Lente, B., Ashwal, L.D., Pandit, M.K., Bowring, S.A., and Torsvik, T.H., 2009. Neoproterozoic hydrothermally altered basaltic rocks from Rajasthan, northwest India: implications for late Precambrian tectonic evolution of the Aravalli craton. Precambrian Research 170, 202-222. [25]

Webb, A.A.G., Yin, A. and Dubey, C.S., 2013.U-Pb zircon geochronology of major lithologic units in the eastern Himalaya: Implications for the origin and assembly of Himalayan rocks. Geological Society of America Bulletin 125, 499-522, doi: 10.1130/B30626.1. [9]

Webb, A.A.G., Yin, A., Harrison, T.M., Celerier, J., Gehrels, G.E., Manning, C.E., Grove, M., 2011. Cenozoic tectonic history of the Himachal Himalaya (NW India) and its constraints on the formation mechanism of the Himalayan orogen. Geosphere 7, 1013-1061. [2]

Yin, A., 2006. Cenozoic tectonic evolution of the Himalayan orogen as constrained by along-strike variation in structural geometry,

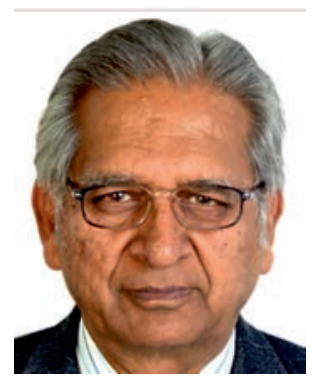

Arvind Kumar Jain is PhD in Geology from erstwhile University of Roorkee (now IIT Roorkee). He worked briefly as Scientist at Wadia Institute of Himalayan Geology, Dehra Dun, and then taught at the IIT Roorkee till 2007. He remained at the Institute as Emeritus Fellow till 2011. Prof. Jain was a Fellow, Alexander von Humboldt Foundation (1979-1981) Germany, Visiting Young Scientist London (1979), Visiting Scientist (1991) Sweden, Senior JSPS Fellow (2004) Japan, and a Fellow Indian National Science Academy (FNA). He has written/edited 5 books and more than 120 publications, including a book on the 'An Introduction to Structural Geology'.

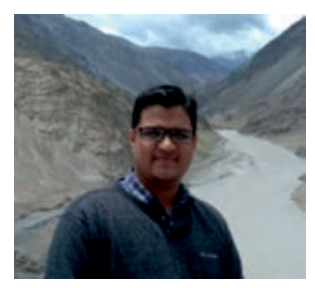

Saurabh Singhal is a Scientist working inPetrology and GeochemistryGroupat Wadia Institute of Himalayan Geology, 33 GMS Road Dehradun since Dec 2014. He is basically a M.Tech. in Electronics and Communication fromNIT Jalandhar.

His research interest is in the field of Analytical Geochemistry andMass Spectrometry for Geochronology and Isotope Geochemistry. He has authored 11 research publications and completed five projects related to Himalayan Geology. exhumation history, and foreland sedimentation. Earth Science Reviews 76, 1-131.

Yin, A., Dubey, C.S., Kelty, T.K., Webb, A.A.G., Harrison, T.M., Chou, C.Y.,Célérier, J., 2010a. Geologic correlation of the Himalayan orogen and Indian craton: Part 2. Structural geology, geochronology, and tectonic evolution of the Eastern Himalaya. Geological Society of America Bulletin 122, 360-395, doi: 10.1130/B26461.1. [7, 10]

Yin, A., Dubey, C.S., Webb, A.A.G., Kelty, T.K., Grove, M., Gehrels, G.E., Burgess, W.P., 2010b. Geological correlation of the Himalayan orogen and Indian craton: Part 1. Structural geology, $\mathrm{U}-\mathrm{Pb}$ zircon geochronology, and tectonic evolution of the Shillong Plateau and its neighboring regions in NE India. Geological Society of America Bulletin 122, 336-359, doi:10.1130/ B26460.1. [8]

Zhao, G.C., Sun, M., Wilde, S.A.,Li, S.Z., 2004. A PaleoMesoproterozoic supercontinent: assembly, growth and breakup. Earth Science Reviews 67, 91-123.

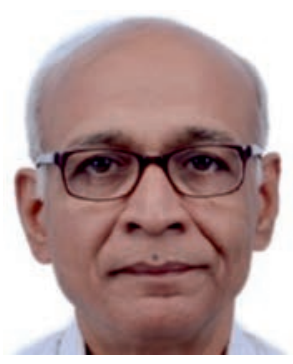

Pulok Kumar Mukherjee obtained his Ph.D. (1986) degree from IIT Roorkee, and joined the Wadia Institute of Himalayan Geology (WIHG). Over a period of more than 30 years he worked on various aspects of Geochemistry, Metamorphism, Magmatism and implications to tectonic history of Himalaya. He developed keen interest in analytical geochemistry and was involved in developing modern analytical facilities, including LA-MC-ICPMS. He was a Visiting Fellow (2017-18) at Texas Tech University (USA) and developed a new technique for $\mathrm{U}-\mathrm{Pb}$ zircon microgeochronology. Currently, he is engaged as Consultant in establishing up-coming National Geochronology Facility at InterUniversity Accelerator Centre (IUAC), New Delhi. 